\title{
REVIEW \\ Nitrogen Dynamics of Organic Materials Applied to Paddy Fields: Direct Evaluation Using Organic Materials Labeled with Nitrogen-15
}

\author{
Mizuhiko NISHIDA* \\ Lowland Crop Rotation Research Team, National Agricultural Research Center for Tohoku Region, \\ National Agriculture and Food Research Organization (Daisen, Akita 014-0102, Japan)
}

\begin{abstract}
In this study, ${ }^{15} \mathrm{~N}$-labeled organic materials were used to evaluate the nitrogen $(\mathrm{N})$ dynamics associated with the application of organic materials to paddy fields. The decomposition of three types of organic materials, namely wheat straw, rice straw, and cattle manure compost, was evaluated by using the glass fiber-filter paper bag method. The $\mathrm{N}$ retention rates obtained by evaluation of $\mathrm{N}$ content were different from those obtained by evaluation of ${ }^{15} \mathrm{~N}$ abundance. The fates of $\mathrm{N}$ in seven types of ${ }^{15} \mathrm{~N}$ labeled organic materials, namely cattle manure compost, poultry manure compost, swine feces, rice straw compost, rice bran, rice straw, and wheat straw, were studied during a crop season in a warm region in Japan. The nitrogen use efficiency for swine feces, poultry manure compost, and rice bran relative to that for chemical fertilizers was as high as approximately $70 \%$, whereas the nitrogen use efficiency for cattle manure compost relative to that for chemical fertilizers was as low as $16-19 \%$. The $\mathrm{N}$ uptake from ${ }^{15} \mathrm{~N}$-labeled swine manure compost or rice bran simultaneously applied with cattle manure compost was slower than those from swine manure compost or rice bran alone. Furthermore, I investigated the fate of $\mathrm{N}$ derived from ${ }^{15} \mathrm{~N}$-labeled cattle manure compost over a period of three years in a region with a cool climate. Well-composted cattle manure compost was found to be a stable $\mathrm{N}$ source for rice plants for at least three years after application. A large amount of $\mathrm{N}$ derived from the cattle manure compost remained in the soil even three years after application.
\end{abstract}

Discipline: Soils, fertilizers and plant nutrition

Additional key words: compost, manure, nitrogen use efficiency, plant residue, rice

\section{Introduction}

Large amounts of organic materials such as plant residues and livestock wastes are produced as by-products of agricultural activities. These by-products should be regarded as valuable resources and not as waste products. The importance of resource-recycling farming systems is being increasingly recognized. This has led to an increase in the demand for agricultural produce, including rice (Oryza sativa. L.), which is grown using organic materials as nutrient sources, thereby leading to the effective use of organic materials in rice farming. In this regard, information about the nitrogen $(\mathrm{N})$ dynamics of organic materials used in paddy fields is indispensable for their effective use in sustainable rice farming.

The $\mathrm{N}$ budget of organic materials applied to the soil has been estimated by the difference method, which is based on the difference between the $\mathrm{N}$ content of soils with and without the amendment of organic materials ${ }^{21}$. The decomposition status of organic $\mathrm{N}$ in fields has been estimated by the glass fiber-filter paper bag (GFPB) method ${ }^{4,5}$. When $\mathrm{N}$ derived from organic materials was focused however, the information from these indirect evaluation methods was insufficient. The amount of $\mathrm{N}$ taken up by plants and remaining in soil derived from applied organic materials, and the temporal changes, could not be precisely evaluated by these methods.

Recent studies have shown that the ${ }^{15} \mathrm{~N}$-labeling technique, in which the activity of ${ }^{15} \mathrm{~N}$ from ${ }^{15} \mathrm{~N}$-labeled organic materials applied to the soil is evaluated directly, is an appropriate method to accurately evaluate the fate of $\mathrm{N}$ in crops and soi ${ }^{3,10,29}$. However, few studies have reported the use of the ${ }^{15} \mathrm{~N}$-labeling technique in rice farming. Moreover, in most of the studies that used the ${ }^{15} \mathrm{~N}$-labeling technique, the experiments were performed in pots, and some of these 
studies were performed in greenhouses ${ }^{9,26}$; thus, the conditions in these experiments were greatly different from conditions in fields. Therefore, the activity of organic-materials $\mathrm{N}$ applied in paddy fields has remained unclear. To precisely elucidate the $\mathrm{N}$ dynamics of organic materials in paddy fields, a series of studies were performed by direct evaluation using ${ }^{15} \mathrm{~N}$-labeled organic materials in warm and cool regions of Japan.

\section{Discrepancy in the $\mathrm{N}$ retention rates of organic materials evaluated by $N$ content and ${ }^{15} \mathrm{~N}$ abundance in the glass fiber-filter paper bag method}

The GFPB method was developed to quantitatively estimate the decomposition of organic materials in field conditions ${ }^{4}$. The $\mathrm{N}$ and the $\mathrm{C}$ retention/decomposition rates can be determined by the GFPB method and are determined on the basis of changes in $\mathrm{N}$ and $\mathrm{C}$ content in the GFPB for a certain period. This method has been used to determine the $\mathrm{N}$ and $\mathrm{C}$ retention/decomposition rates of various organic materials in various soil conditions ${ }^{5,11,19}$. However, the ${ }^{15} \mathrm{~N}$-labeling technique has not been used with the GFPB method. To precisely evaluate the decomposition status of

Table 1. Chemical properties of ${ }^{15} \mathrm{~N}$-labeled organic materials and soil

\begin{tabular}{lcccc}
\hline \hline & $\begin{array}{c}\mathrm{T}-\mathrm{N} \\
\left(\mathrm{g} \mathrm{kg}^{-1}\right)\end{array}$ & $\begin{array}{c}{ }^{15} \mathrm{~N} \\
\left(\mathrm{atom}^{2}\right)\end{array}$ & $\begin{array}{c}\mathrm{T}-\mathrm{C} \\
\left(\mathrm{g} \mathrm{kg}^{-1}\right)\end{array}$ & $\mathrm{C} / \mathrm{N}$ \\
\hline Wheat straw & 2.25 & 7.14 & 424 & 188 \\
Rice straw & 10.1 & 4.93 & 408 & 40 \\
Cattle manure compost & 13.1 & 2.38 & 307 & 23 \\
Soil & 2.21 & - & 27.3 & 12 \\
\hline
\end{tabular}

Dry weight basis. organic $\mathrm{N},{ }^{15} \mathrm{~N}$-labeled organic materials were used in the GFPB method in a paddy field of the National Agricultural Research Center for Kyushu Okinawa Region (KONARC) in Chikugo, which is a warm region of Japan ${ }^{13}$. The chemical properties of the tested organic materials, such as wheat straw (WS), rice straw (RS), and cattle manure compost (CMC), are shown in Table 1. The soil in the KONARC paddy field was fine-textured Gray Lowland soil [classified as Fluvisol by the World Reference Base for soil resources $(\mathrm{WRB})^{1}$ ]. A mixture of soil and organic materials was put into the GFPB as described by Maeda and Onikura ${ }^{4}$, and the GFPB was placed at about $5 \mathrm{~cm}$ below ground in the paddy field in 2000.

For all three types of organic materials examined, the $\mathrm{N}$ retention rate obtained by evaluation of the $\mathrm{N}$ content was different from that obtained by evaluation of ${ }^{15} \mathrm{~N}$ abundance (Fig. 1). The $\mathrm{N}$ retention rate obtained by evaluation of ${ }^{15} \mathrm{~N}$ abundance indicated loss of organic N; however, in the cases of WS and RS, the N retention rates obtained by evaluation of $\mathrm{N}$ content were higher than $100 \%$ throughout the experimental period. It was hypothesized that $\mathrm{N}$ flows into the GFPB in the case of organic materials with a high $\mathrm{C} / \mathrm{N}$ ratio $^{5}$. I confirmed that $\mathrm{N}$ inflow and outflow from the GFPB occurred simultaneously regardless of the $\mathrm{C} / \mathrm{N}$ ratio of the organic materials. The differences between the $\mathrm{N}$ retention rates obtained by evaluation of $\mathrm{N}$ content and ${ }^{15} \mathrm{~N}$ abundance increased with an increase in the $\mathrm{C} / \mathrm{N}$ ratio of the organic materials. Nitrogen inflow into the GFPB was greatest in $\mathrm{WS}$, which had the highest $\mathrm{C} / \mathrm{N}$ ratio. This finding can be attributed to the immobilization of $\mathrm{N}$ from outside the GFPB by microorganisms under C-rich conditions. Nitrogen inflow into the GFPB increased throughout the experimental period in WS, whereas that in CMC scarcely increased; $\mathrm{CMC}$ had the lowest $\mathrm{C} / \mathrm{N}$ ratio. These results indicated that the GFPB method, which is based on changes
Wheat straw

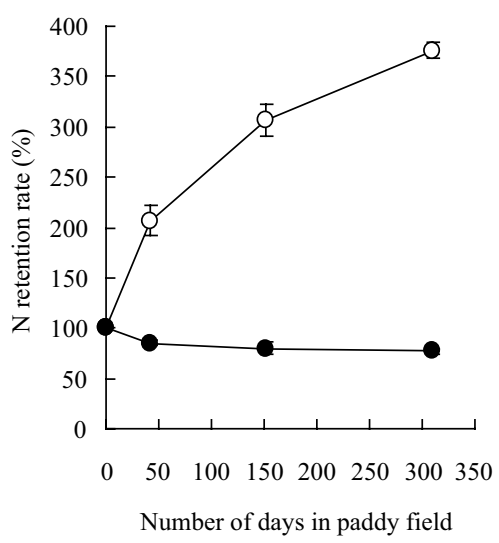

Rice straw

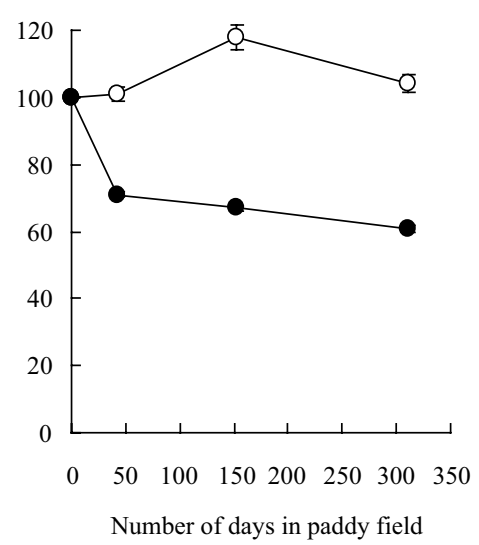

Cattle manure compost

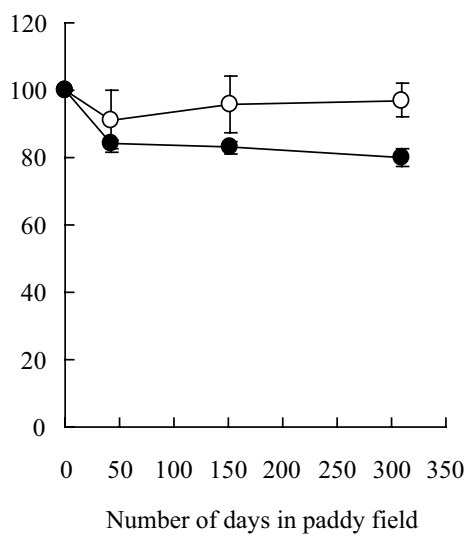

Fig. 1. The nitrogen retention rate of ${ }^{15} \mathrm{~N}$-labeled organic materials in the glass fiber-filter paper bag (GFPB) method evaluated by the $\mathrm{N}$ content in GFPB and by ${ }^{15} \mathrm{~N}$ abundance in GFPB

$\bigcirc$ : evaluated by $\mathrm{N}$ content, $\mathrm{O}$ : evaluated by ${ }^{15} \mathrm{~N}$ abundance. Error bars indicate standard error. 
in $\mathrm{N}$ content, does not necessarily reflect the decomposition status of organic $\mathrm{N}$. Therefore, to estimate the retention status of organic-materials $\mathrm{N}$, a test with ${ }^{15} \mathrm{~N}$-labeled organic materials would be the appropriate method, especially for organic materials with a high $\mathrm{C} / \mathrm{N}$ ratio.

\section{Fate of $\mathrm{N}$ in ${ }^{15} \mathrm{~N}$-labeled organic materials applied to a paddy field in a warm region of Japan}

\section{N-distribution characteristics of organic materials}

To clarify the fate of organic-materials $\mathrm{N}$ in a paddy field, seven types of ${ }^{15} \mathrm{~N}$-labeled organic materials were applied to transplanted rice ${ }^{14}$. This field experiment was performed in micro-plots in a paddy field at KONARC in 1998. The ${ }^{15} \mathrm{~N}$-labeled organic materials applied to transplanted rice plants were CMC, poultry manure compost (PMC), swine feces (SF), rice straw compost (RSC), rice bran (RB), RS, and WS (Table 2).

The $\mathrm{N}$ distribution in the uptake of organic materials by the plants, i.e., nitrogen use efficiency (NUE: percentage of $\mathrm{N}$ uptake from the applied amount of $\mathrm{N}$ to the amount of applied $\mathrm{N}$ ), varied significantly for different types of organic materials. The NUEs of PMC, SF, and RB were signifi- cantly higher than those of the other organic materials (Fig. 2). CMC had the lowest NUE. The relative efficiency of

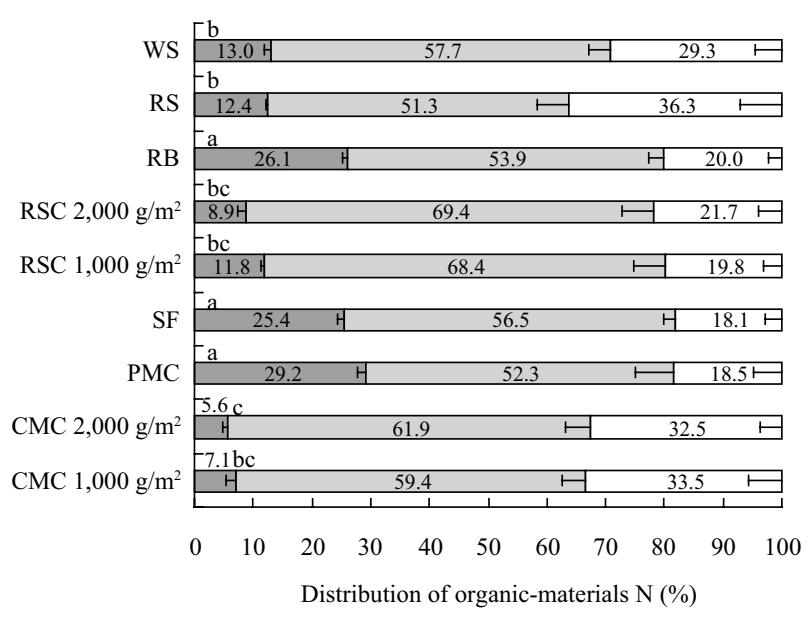

Fig. 2. Distribution of nitrogen derived from ${ }^{15} \mathrm{~N}$ labeled organic materials at the maturity stage Error bars indicate standard error. Distribution to plant with same letters are not significantly different by the Tukey-Kramer test $(p<0.05)$. CMC: cattle manure compost, PMC: poultry manure compost, SF: swine feces, RSC: rice straw compost, RB: rice bran, RS: rice straw, WS: wheat straw. $\square$ : Plant, $\square$ : Soil, $\square$ : Unrecovered.

Table 2. Application rates and chemical properties of ${ }^{15} \mathrm{~N}$-labeled organic materials

\begin{tabular}{lcccccccc}
\hline \hline & $\begin{array}{c}\text { Applied F.W. } \\
\left(\mathrm{g} \mathrm{m}^{-2}\right)\end{array}$ & $\begin{array}{c}\mathrm{T}-\mathrm{N} \\
\left(\mathrm{g} \mathrm{kg}^{-1}\right)\end{array}$ & $\begin{array}{c}\text { Applied N } \\
\left(\mathrm{g} \mathrm{m}^{-2}\right)\end{array}$ & $\begin{array}{c}{ }^{15} \mathrm{~N} \\
(\text { atom } \%)\end{array}$ & $\begin{array}{c}\mathrm{T}-\mathrm{C} \\
\left(\mathrm{g} \mathrm{kg}^{-1}\right)\end{array}$ & $\mathrm{C} / \mathrm{N}$ & $\begin{array}{c}\mathrm{NH}_{4}-\mathrm{N} / \mathrm{T}-\mathrm{N} \\
(\%)\end{array}$ & $\begin{array}{c}\text { Moisture } \\
\left(\mathrm{g} \mathrm{g}^{-1}\right)\end{array}$ \\
\hline Cattle manure compost & $1,000 / 2,000$ & 4.41 & $4.41 / 8.82$ & 4.57 & 138 & 31 & 0.9 & 0.71 \\
Poultry manure compost & 1,000 & 30.9 & 30.9 & 2.06 & 389 & 13 & 33 & 0.07 \\
Swine feces & 1,000 & 45.9 & 45.9 & 2.83 & 429 & 9.3 & 2.9 & 0.07 \\
Rice straw compost & $1,000 / 2,000$ & 2.79 & $2.79 / 5.58$ & 6.83 & 92.3 & 33 & 1.1 & 0.87 \\
Rice bran & 500 & 25.0 & 12.5 & 6.90 & 405 & 16 & 0.1 & 0.18 \\
Rice straw & 500 & 6.46 & 3.23 & 6.84 & 348 & 54 & 0.7 & 0.07 \\
Wheat straw & 500 & 3.74 & 1.87 & 4.53 & 416 & 111 & 0.8 & 0.07 \\
\hline
\end{tabular}

Fresh weight basis.

Table 3. Estimation of the relative efficiency ${ }^{\text {a) }}$ and other properties of organic materials in paddy field by using the ${ }^{15} \mathrm{~N}$ labeling technique

\begin{tabular}{|c|c|c|c|c|}
\hline & $\begin{array}{l}\text { Applied F.W. } \\
\qquad\left(\mathrm{g} \mathrm{m}^{-2}\right)\end{array}$ & $\begin{array}{c}\text { Relative efficiency } \\
(\%)\end{array}$ & $\begin{array}{l}\text { Period of } \mathrm{N} \text { uptake from } \\
\text { organic materials }\end{array}$ & Remarks on retention/loss \\
\hline Cattle manure compost & $1,000-2,000$ & 16-19 & All growth period & High retention and loss rates \\
\hline Poultry manure compost & 1,000 & $81(72)^{b)}$ & Mostly before $\mathrm{PI}^{\mathrm{c})}$-booting stage & \\
\hline Swine feces & 1,000 & 71 & All growth period & \\
\hline Rice straw compost & $1,000-2,000$ & $25-31$ & Mostly before PI-booting stage & High retention rate \\
\hline Rice bran & 500 & 73 & Mostly before PI-booting stage & \\
\hline Rice straw & 500 & 33 & Before PI-booting stage & High loss rate \\
\hline Wheat straw & 500 & 34 & Before PI-booting stage & \\
\hline
\end{tabular}

a): Relative efficiency of organic materials $\mathrm{N}$ to that of chemical fertilizer.

b): Value in parentheses was calculated excluding the inherent $\mathrm{NH}_{4}-\mathrm{N}$ of poultry manure compost.

c): Panicle initiation. 
organic-materials $\mathrm{N}$ to chemical fertilizer was calculated using the NUE value for ${ }^{15} \mathrm{~N}$-labeled ammonium sulfate (Table 3). The relative NUEs of PMC, SF, and RB were as high as approximately $70 \%$, indicating that $70 \%$ of the $\mathrm{N}$ in these organic materials can substitute for chemical fertilizer $\mathrm{N}$. In the cases of SF and CMC, the uptake of organic-materials $\mathrm{N}$ continued throughout the rice growth period, while it declined remarkably 54 days after transplanting (DAT; panicle initiation to booting stage) in other organic materials (data not shown).

The loss of $\mathrm{N}$ from the organic materials can account for most of the unrecovered organic-materials N. No significant difference was observed in the $\mathrm{N}$ distributions to soil and unrecovered among the tested organic materials. However, I found that the $\mathrm{N}$ retention rates for RSC and $\mathrm{CMC}$ and the $\mathrm{N}$ loss rates for $\mathrm{CMC}$, RS, and WS were high.

\section{Changes in the $\mathrm{N}$-uptake process from organic materials by simultaneous application with CMC}

Cattle wastes account for the largest proportion of $\mathrm{N}$ generated from livestock farming ${ }^{6}$. Since a large amount of $\mathrm{N}$ is generated from cattle farming, methods should be developed to effectively use CMC in the production of various types of crops. However, CMC has low NUE when applied to rice plants as described above. Application of $\mathrm{CMC}$ along with other organic materials with higher NUE or faster rate of uptake can be employed for the effective use of $\mathrm{CMC}^{6}$. Simultaneous application of CMC with another $\mathrm{N}$ source may cause changes in the $\mathrm{N}$-uptake process by rice plants. For example, the ${ }^{15} \mathrm{~N}$ uptake after simultaneous application of ${ }^{15} \mathrm{~N}$-labeled ammonium sulfate (AS) and $\mathrm{CMC}$ was slower than that after the application of ${ }^{15} \mathrm{~N}$ labeled AS alone ${ }^{8}$. However, the $\mathrm{N}$-uptake process after simultaneous application of organic materials and CMC to rice plants has not been directly evaluated using ${ }^{15} \mathrm{~N}$-labeled organic materials. The $\mathrm{N}$-uptake process after simultaneous application of swine manure compost (SMC) and RB with CMC was investigated using the ${ }^{15} \mathrm{~N}$-labeling technique in direct-seeded rice grown in micro-plots in the paddy field at KONARC in $2000^{15}$. The application design and chemical properties of the organic materials are shown in Tables 4 and 5 , respectively.

At 55 days after seeding (DAS), the NUEs in the plots with $\mathrm{CMC}$ were significantly lower than those in the plots without CMC (Fig. 3). The period of 55 DAS corresponded to the tillering stage. At 91 DAS (heading stage) and 140 DAS (maturity stage), the NUEs in these plots were almost similar and no significant difference was observed. Consequently, the $\mathrm{N}$ uptake from organic materials after simultaneous application of SMC, RB, and AS with CMC was slower than that after application of these organic materials alone. Immobilization of inorganic $\mathrm{N}$ is promoted by the addition of organic materials with a $\mathrm{C} / \mathrm{N}$ ratio higher than approximately $20^{25}$. Since the $\mathrm{C} / \mathrm{N}$ ratio of the $\mathrm{CMC}$ used in this experiment was 27 , I expected immobilization of $\mathrm{N}$ in case of co-application of AS and CMC; therefore, at 55 DAS, the NUE of AS in a plot in which AS was simultaneously applied with $\mathrm{CMC}$ would be lower than that of AS alone. A similar phenomenon might have occurred after application of CMC with SMC and RB. A substantial part of the mineralized $\mathrm{N}$ from SMC and RB might have been re-immobilized during the early growth period, followed by remineralization and uptake by rice plants.

Table 4. Application design of the field experiment

\begin{tabular}{|c|c|c|c|c|c|}
\hline \multirow[t]{2}{*}{ Plot } & \multicolumn{3}{|c|}{${ }^{15} \mathrm{~N}$-labeled material } & \multicolumn{2}{|c|}{ Cattle manure compost } \\
\hline & Applied material & $\begin{array}{l}\text { Applied F.W. } \\
\left(\mathrm{g} \mathrm{m}^{-2}\right)\end{array}$ & $\begin{array}{l}\text { Applied N } \\
\left(\mathrm{g} \mathrm{m}^{-2}\right)\end{array}$ & $\begin{array}{l}\text { Applied F.W. } \\
\left(\mathrm{g} \mathrm{m}^{-2}\right)\end{array}$ & $\begin{array}{c}\text { Applied N } \\
\left(\mathrm{g} \mathrm{m}^{-2}\right)\end{array}$ \\
\hline${ }^{15} \mathrm{~N}-\mathrm{SMC}$ & Swine manure compost & 1,980 & 40 & 0 & 0 \\
\hline${ }^{15} \mathrm{~N}-\mathrm{SMC}+\mathrm{CMC}$ & Swine manure compost & 990 & 20 & 3,610 & 20 \\
\hline${ }^{15} \mathrm{~N}-\mathrm{RB}$ & Rice bran & 500 & 6.3 & 0 & 0 \\
\hline${ }^{15} \mathrm{~N}-\mathrm{RB}+\mathrm{CMC}$ & Rice bran & 500 & 6.3 & 3,610 & 20 \\
\hline${ }^{15} \mathrm{~N}-\mathrm{AS}$ & Ammonium sulfate & 23.6 & 5 & 0 & 0 \\
\hline${ }^{15} \mathrm{~N}-\mathrm{AS}+\mathrm{CMC}$ & Ammonium sulfate & 23.6 & 5 & 3,610 & 20 \\
\hline
\end{tabular}

Table 5. Chemical properties of organic materials

\begin{tabular}{lcccrrrr}
\hline \hline Organic materials & $\begin{array}{c}\mathrm{T}-\mathrm{N} \\
\left(\mathrm{g} \mathrm{kg}^{-1}\right)\end{array}$ & $\begin{array}{c}{ }^{15} \mathrm{~N} \\
(\mathrm{atom} \%)\end{array}$ & $\begin{array}{c}\mathrm{T}-\mathrm{C} \\
\left(\mathrm{g} \mathrm{kg}^{-1}\right)\end{array}$ & $\mathrm{C} / \mathrm{N}$ & $\begin{array}{c}\mathrm{NH}_{4}-\mathrm{N} \\
\left(\mathrm{mg} \mathrm{kg}^{-1}\right)\end{array}$ & $\begin{array}{c}\mathrm{NO}_{3}-\mathrm{N} \\
\left(\mathrm{mg} \mathrm{kg}^{-1}\right)\end{array}$ & $\begin{array}{c}\text { Moisture } \\
\left(\mathrm{g} \mathrm{g}^{-1}\right)\end{array}$ \\
\hline Cattle manure compost & 5.54 & 0.369 & 150 & 27 & 6 & 10 & 0.64 \\
Swine manure compost $\left({ }^{15}\right.$ N-labeled $)$ & 20.2 & 1.39 & 123 & 6 & 129 & 10 & 0.50 \\
Rice bran $\left({ }^{15}\right.$ N-labeled) & 12.5 & 8.68 & 331 & 26 & 76 & Trace & 0.16 \\
\hline
\end{tabular}

Fresh weight basis. 

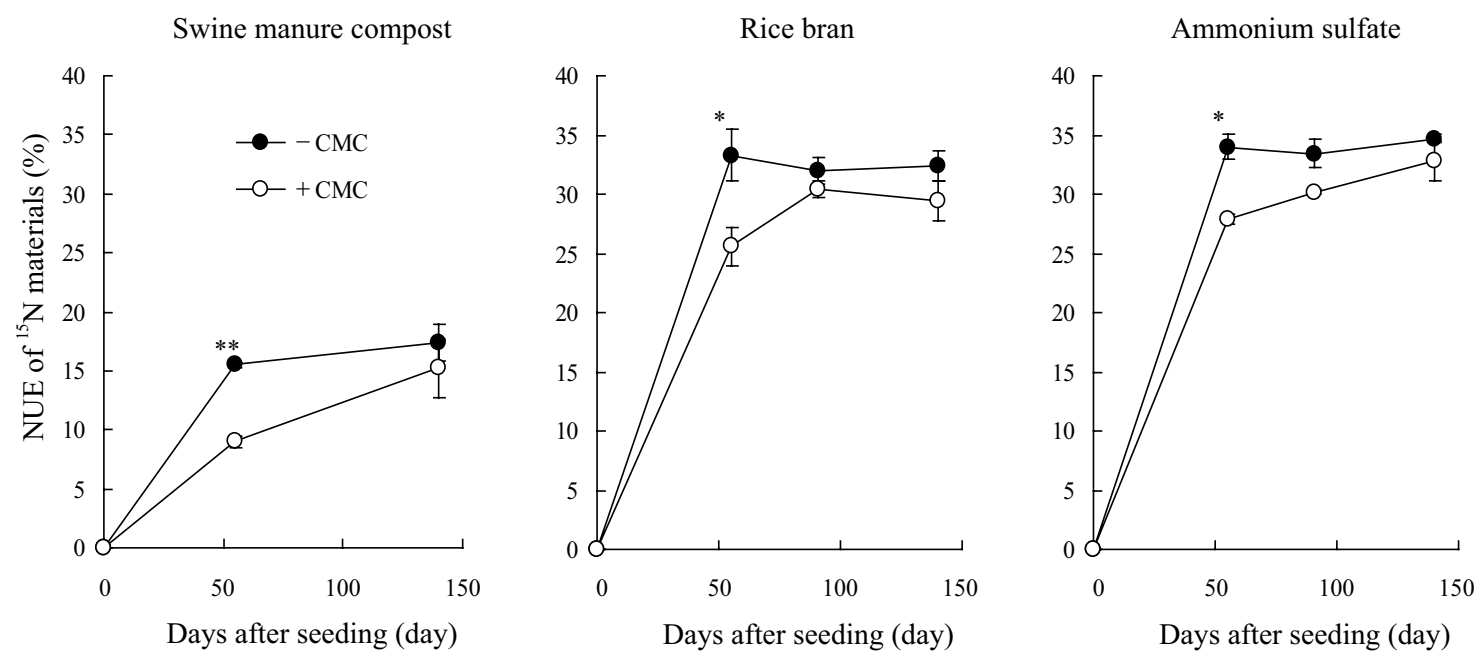

Fig. 3. Temporal changes in the nitrogen use efficiency (NUE) of ${ }^{15} \mathrm{~N}$-labeled swine manure compost, rice bran and ammonium sulfate applied with/without cattle manure compost (CMC)

$\bigcirc$ : with $\mathrm{CMC}$, without CMC. Error bars indicate standard error. Significant differences between treatments at each sampling time are indicated by $^{*},{ }^{* *}=p<0.05,0.01$, respectively.

Table 6. Chemical properties of ${ }^{15} \mathrm{~N}$-labeled cattle manure compost

\begin{tabular}{ccccccc}
\hline $\begin{array}{c}\mathrm{T}-\mathrm{N} \\
\left(\mathrm{g} \mathrm{kg}^{-1}\right)\end{array}$ & $\begin{array}{c}{ }^{15} \mathrm{~N} \\
(\text { atom\%) }\end{array}$ & $\begin{array}{c}\mathrm{T}-\mathrm{C} \\
\left(\mathrm{g} \mathrm{kg}^{-1}\right)\end{array}$ & \begin{tabular}{c}
$\mathrm{C} / \mathrm{N}$ \\
\hline 3.95
\end{tabular} & $\begin{array}{c}\mathrm{NH}_{4}-\mathrm{N} \\
\left(\mathrm{mg} \mathrm{kg}^{-1}\right)\end{array}$ & $\begin{array}{c}\mathrm{NO}_{3}-\mathrm{N} \\
\left(\mathrm{mg} \mathrm{kg}^{-1}\right)\end{array}$ & $\begin{array}{c}\text { Moisture } \\
\left(\mathrm{g} \mathrm{g}^{-1}\right)\end{array}$ \\
\hline
\end{tabular}

Fresh weight basis.

Although the NUE of CMC was low, the rice yield increased after more than three years of repeated application of $\mathrm{CMC}^{18,27}$. Thus, the effect of CMC on rice production becomes apparent after multiple applications over a certain period. Therefore, I suggest that CMC should be used with other $\mathrm{N}$ sources with a higher efficiency or quicker efficiency, thereby facilitating adequate $\mathrm{N}$ supply to plants until sufficient $\mathrm{N}$ is released from $\mathrm{CMC}$. However, it should be noted that $\mathrm{N}$ uptake from other organic materials can also slow down when these materials are simultaneously applied with CMC. This observation also implies that the NUE of organic materials can be controlled by combining them with other organic materials.

\section{Fate of $\mathrm{N}$ derived from ${ }^{15} \mathrm{~N}$-labeled CMC applied to a paddy field in a cool region of Japan}

Several studies have reported the $\mathrm{N}$ dynamics for ${ }^{15} \mathrm{~N}-$ labeled livestock manure in paddy fields in warm regions of

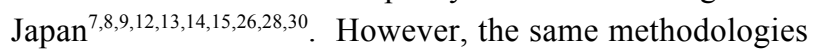
and techniques have not been applied in cool regions of the country. Therefore, the $\mathrm{N}$ dynamics for livestock manure in paddy fields in cool regions remain unclear. Thus far, only two studies have reported multiple-year monitoring of ${ }^{15} \mathrm{~N}$ applied in paddy soils ${ }^{9,26}$. In these studies, the uptake of ${ }^{15} \mathrm{~N}$ in livestock manure by rice plants over multiple years was confirmed, and this finding showed the significance of multiple-year observations in determining the uptake of organicmaterials $\mathrm{N}$. To investigate the fate of $\mathrm{N}$ derived from $\mathrm{CMC}$ in cool regions of Japan, ${ }^{15} \mathrm{~N}$-labeled CMC was applied at rates of 1,2 , and $4 \mathrm{~kg} \mathrm{~m}^{-2}$ in a microplot field experiment performed at the National Agricultural Research Center for Tohoku Region (NARCT) in Daisen, which is a district in northeastern Japan ${ }^{17}$. In this study, ${ }^{15} \mathrm{~N}$-labeled CMC was applied in 2000 and monitored until 2002. The chemical properties of ${ }^{15} \mathrm{~N}$-labeled CMC are listed in Table 6. The soil in the paddy field of NARCT was fine-textured Gray Lowland soil (classified as Fluvisol by $\mathrm{WRB}^{1}$ ), and the soil in the plow layer contained $2.35 \mathrm{~g} \mathrm{~kg}^{-1}$ of total $\mathrm{N}$ on a dry weight basis.

In this study, the distribution of the $\mathrm{N}$ derived from $\mathrm{CMC}$ at the end of the third crop season was as follows: $6.9-7.3 \%$ in the rice plants, $66-69 \%$ in the soil, and $24-27 \%$ unrecovered $\mathrm{N}$ (Fig. 4). These distributions were similar at all application rates. The $\mathrm{N}$ uptake from $\mathrm{CMC}$ by the rice plants did not show a marked decrease throughout the experimental period of three crop seasons. The rates of $\mathrm{N}$ uptake from $\mathrm{CMC}$ by rice plants at the panicle initiation, heading, and maturity stages were $1-2 \%, 2 \%$, and $2-3 \%$, respectively, of the total $\mathrm{N}$ derived from $\mathrm{CMC}$ (data not shown). Thus, the $\mathrm{N}$ in $\mathrm{CMC}$ was a stable $\mathrm{N}$ source for rice plants throughout the three-year growth period. The relationship between the number of days transformed to standard temperature at $25^{\circ} \mathrm{C}(\mathrm{DTS})^{20}$ and the cumulative amount of CMC N taken up by the rice plants (Ndfc) over the three-year period is shown in Fig. 5. A significant positive linear correlation was found between the DTS and the 

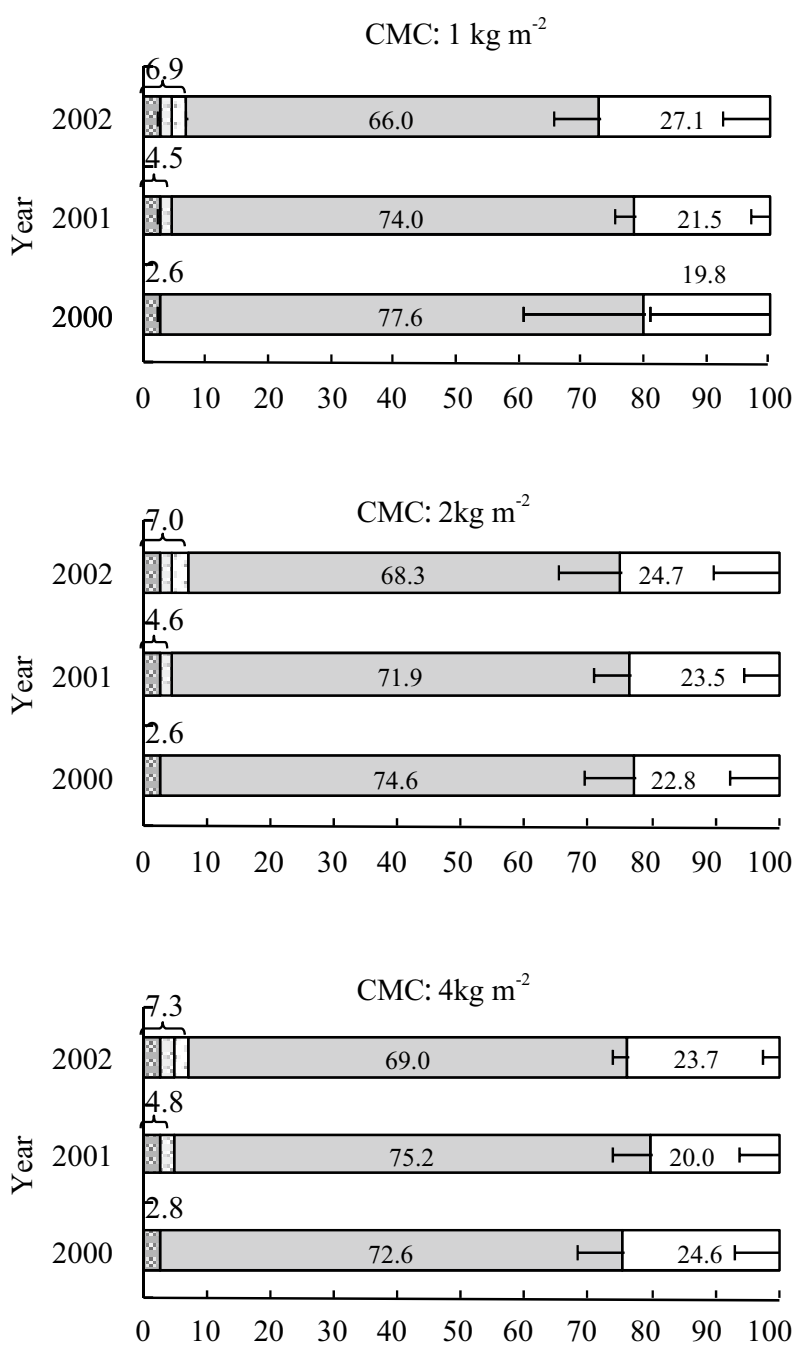

Distribution of CMC N (\%)

Fig. 4. Distribution of $\mathrm{N}$ derived from ${ }^{15} \mathrm{~N}$-labeled cattle manure compost (CMC) at the maturity stage during each crop season.

Error bars indicate standard deviation.

图: Plant(2000), 囦: Plant(2001), [: Plant(2002), ๑: Soil, ๘: Unrecovered.

cumulative Ndfc, which suggested that the mineralization of $\mathrm{N}$ derived from $\mathrm{CMC}$ and its uptake by rice plants depended on temperature.

A large amount of $\mathrm{N}$ from the compost (approximately $70 \%$ ) remained in the soil even after the third crop season. This $\mathrm{N}$ would continue to serve as an $\mathrm{N}$ source for rice plants. The greatest amount of $\mathrm{N}$ loss (unrecovered $\mathrm{N}$ ) was observed in the first crop season. The reason for this finding is unclear. Although the tested CMC was highly matured, the inherent inorganic $\mathrm{N}$ and the $\mathrm{N}$ in the easily decomposable organic matter in CMC might be lost during the early growth period in the first crop season before the root system is well developed.

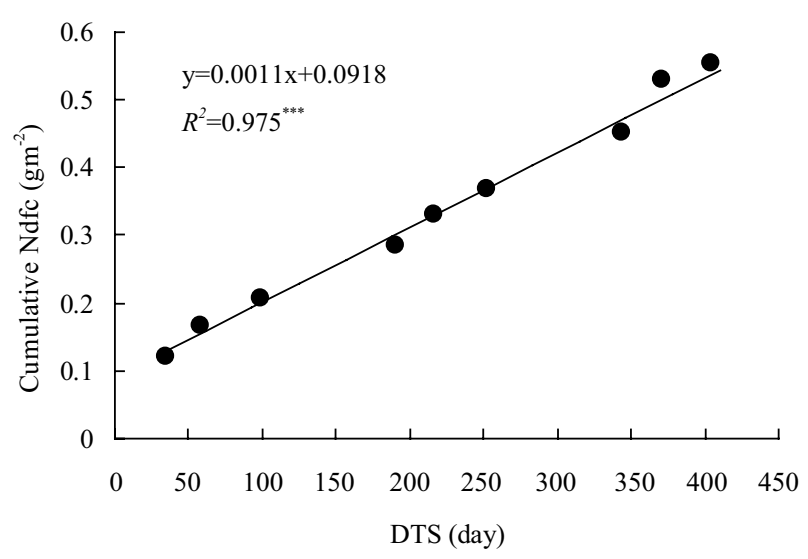

Fig. 5. Relationship between the number of days transformed to a standard temperature at $25^{\circ} \mathrm{C}$ (DTS) over the entire experimental period and the cumulative $\mathrm{N}$ uptake from ${ }^{15} \mathrm{~N}$-labeled cattle manure compost (CMC) at an application rate of $2 \mathrm{~kg} \mathrm{~m}^{-2}$ Ndfc: $\mathrm{N}$ uptake originated from CMC. ${ }^{* * *} p<0.001$.

\section{NUE of compost in the previous studies and research perspectives}

The NUE values of ${ }^{15} \mathrm{~N}$-labeled composts used in previous studies and in this study are summarized in Table 7. The NUE of PMC tended to be higher than that of CMC, which is in accordance with the results of indirect methods (difference method) ${ }^{2}$. The NUE of RSC was likely to be low. The NUEs of various types of compost were different. This variation can be attributed to differences in the properties of the composts, including the maturity of the composts and the additives used for composting, and environmental factors such as the nature of the soil and the climate. Further studies are required to precisely determine the relationship between the properties of compost and the $\mathrm{N}$ dynamics after application of the compost.

In addition, I observed that a considerable proportion of organic-materials $\mathrm{N}$ remained in the soil after the crop season. Therefore, observation should be performed for a longer period. Organic materials are often repeatedly used by farmers. Therefore, the effect of successively applied organic $\mathrm{N}$ on rice plants, paddy soil, and environment should be quantified by using the ${ }^{15} \mathrm{~N}$-labeling technique.

Recently, a study showed that the contribution of different $\mathrm{N}$ sources, namely manure, chemical fertilizer, and soil, in the $\mathrm{N}$ uptake of rice plants can be determined by estimating natural ${ }^{15} \mathrm{~N}$ abundance $\left(\delta^{15} \mathrm{~N}\right)^{24}$. The factors that affect the $\delta^{15} \mathrm{~N}$ values of paddy soils have been reported ${ }^{16}$. These findings indicate the possibility that $\delta^{15} \mathrm{~N}$ values can be used as tracers in paddy fields. The use of $\delta^{15} \mathrm{~N}$ values for tracing the applied $\mathrm{N}$ is regarded as a direct technique for the evaluation of $\mathrm{N}$ dynamics in paddy fields. The use 
Table 7. Nitrogen use efficiency (NUE) of the compost evaluated by the ${ }^{15} \mathrm{~N}$-labeling technique in rice plants

\begin{tabular}{|c|c|c|c|}
\hline Type of compost & NUE (\%) & $\mathrm{C} / \mathrm{N}$ & Remarks \\
\hline Cattle manure compost & $\begin{array}{c}2.6-2.8 \\
4.0 \\
4.2 \\
5.6 \\
5.6-7.1 \\
6.0-9.2 \\
6.0 \\
11.0 / 13.7 \\
12.3 / 14.9 \\
16.5-17.7 \\
17.4-17.8\end{array}$ & $\begin{array}{c}24 \\
37 \\
18 \\
38 \\
31 \\
26 \\
10 \\
34 / 16 \\
\text { No data } \\
10 \\
10\end{array}$ & 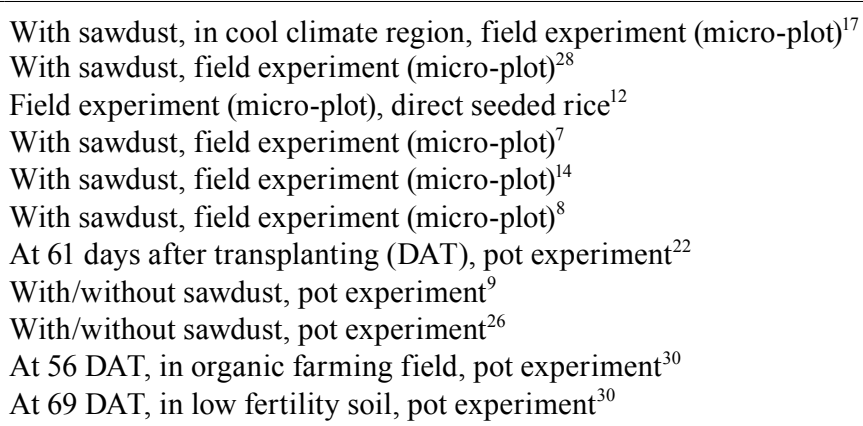 \\
\hline Swine manure compost & $\begin{array}{c}15.2-17.4 \\
18.7\end{array}$ & $\begin{array}{l}6 \\
6\end{array}$ & $\begin{array}{l}\text { Field experiment (micro-plot), direct seeded rice }{ }^{15} \\
\text { Field experiment (micro-plot), direct seeded rice }\end{array}$ \\
\hline Poultry manure compost & $\begin{array}{l}13.8 \\
15.7 \\
29.2\end{array}$ & $\begin{array}{l}10 \\
10 \\
13\end{array}$ & $\begin{array}{l}\text { Field experiment (micro-plot) } \\
\text { Field experiment (micro-plot) } \\
\text { Field experiment (micro-plot) }^{28}\end{array}$ \\
\hline Rice straw compost & $\begin{array}{c}4.4 \\
5.0 \\
7.7 \\
8.9-11.8\end{array}$ & $\begin{array}{c}22 \\
20 \\
\text { No data } \\
33\end{array}$ & $\begin{array}{l}\text { Pot experiment }{ }^{23} \\
\text { Pot experiment }{ }^{9} \\
\text { Pot experiment }{ }^{26} \\
\text { Field experiment (micro-plot) }\end{array}$ \\
\hline
\end{tabular}

of this technique reduces the labor and time required for preparing ${ }^{15} \mathrm{~N}$-labeled organic materials and facilitates in situ evaluation of $\mathrm{N}$ dynamics in paddy fields cultivated by farmers. Since this is a promising technique, further studies should be performed to determine the prospects for using $\delta^{15} \mathrm{~N}$ values as a tool to evaluate the $\mathrm{N}$ dynamics of organic materials used in paddy fields.

\section{References}

1. FAO, ISRIC \& ISSS (1998) World Reference Base for Soil Resources. FAO, Rome, Italy. pp. 88.

2. Harada, Y. (1998) Application rate of processed animal wastes. In Kachikufunnyou shori riyou no tebiki (Guide of processing and utilization of animal wastes), ed. Livestock Industry's Environmental Improvement Organization (LEIO), LEIO, Tokyo, 68-73 [In Japanese].

3. Hood, R.C. et al. (1999) A comparison of direct and indirect ${ }^{15} \mathrm{~N}$ isotope techniques for estimating crop $\mathrm{N}$ uptake from organic residues. Plant Soil, 208, 250-270.

4. Maeda, K. \& Onikura, Y. (1977) A method to determine decomposition of applied organic matters under field conditions. Nippon dojo-hiryogaku zasshi (Jpn. J. Soil Sci. Plant Nutr.), 48, 567-568 [In Japanese].

5. Maeda, K. \& Shiga, H. (1978) Year-long decomposition process of various organic materials in a lowland field. Nippon dojo-hiryogaku zasshi (Jpn. J. Soil Sci. Plant Nutr.), 49, 455460 [In Japanese].

6. Matsumoto, J. (1999) Current issues and approach for animal waste management and utilization in southern Kyushu regions of intensive livestock production. Nippon dojohiryogaku zasshi (Jpn. J. Soil Sci. Plant Nutr.), 70, 487-492 [In Japanese].
7. Matsushita, K. et al. (2000) Kinetics of ${ }^{15} \mathrm{~N}$-labelled nitrogen from co-compost made from cattle manure and chemical fertilizer in a paddy field. Soil Sci. Plant Nutr., 46, 353-363.

8. Matsushita, K. et al. (2000) Kinetics of ${ }^{15} \mathrm{~N}$-labelled nitrogen from co-compost made from cattle manure and chemical fertilizer in a paddy field: Effect of mixing ratio of cattle feces and ammonium sulfate. Soil Sci. Plant Nutr., 46, 905-916.

9. Matsuyama, M. et al. (2003) Nitrogen uptake by rice plants from applied organic matters during five years in pot experiments and reduction in the rate of nitrogen fertilizer application. Nippon dojo-hiryogaku zasshi (Jpn. J. Soil Sci. Plant Nutr.), 74, 533-537 [In Japanese].

10. Muñoz, G.R. et al. (2003) Nitrogen budget and soil N dynamics after multiple application of unlabeled or ${ }^{15}$ Nitrogenenriched dairy manure. Soil Sci. Soc. Am. J., 67, 817-825.

11. Murayama, S. et al. (1990) Chemical properties of subsurface peats and their decomposition kinetics under field conditions. Soil Sci. Plant Nutr., 36, 129-140.

12. Nishida, M. et al. (2001) Availability of nitrogen of organic matters applied to direct seeded rice in warm region, Japan. Kyushu nogyo kenkyu (Kyushu Agric. Res.), 63, 58 [In Japanese].

13. Nishida, M. et al. (2003) Demonstration of discrepancy in $\mathrm{N}$ remaining rate of organic matter evaluated by $\mathrm{N}$ content and ${ }^{15} \mathrm{~N}$ content in the glass fiber-filter paper bag method. Soil Sci. Plant Nutr., 49, 297-300.

14. Nishida, M. et al. (2004) Fate of $\mathrm{N}$ and relative efficiency of ${ }^{15} \mathrm{~N}$-labeled organic materials applied to transplanted rice in northern Kyushu region of Japan. Soil Sci. Plant Nutr., 50, 225-232.

15. Nishida, M. et al. (2005) Changes in the $\mathrm{N}$ recovery process from ${ }^{15} \mathrm{~N}$-labeled swine manure compost and rice bran in direct-seeded rice by simultaneous application of cattle manure compost. Soil Sci. Plant Nutr., 51, 577-581.

16. Nishida, M. et al. (2007) Changes in natural ${ }^{15} \mathrm{~N}$ abundance 
in paddy soils under different, long-term soil management regimes in the Tohoku region of Japan. Soil Sci. Plant Nutr., 53, 310-317.

17. Nishida, M. et al. (2008) Fate of nitrogen derived from ${ }^{15} \mathrm{~N}$ labeled cattle manure compost applied to a paddy field in the cool climate region of Japan. Soil Sci. Plant Nutr., 54, 459466.

18. Ohyama, N. et al. (1998) Effects of long term application of organic materials to the paddy field originated from Aso volcanic ash on the soil fertility and rice growth. I. Effects on the rice growth and nutrient uptake for the initial three years. Kyushu Tokai daigaku nogakubu kiyo (Proceedings of Faculty of Agriculture, Kyushu Tokai University), 17, 9-24 [In Japanese with English summary].

19. Sato, K. \& Nakamura, K. (2000) Estimation of nitrogen mineralization of animal manure-coffee residue compost and influences on paddy rice. Nippon dojo-hiryogaku zasshi (Jpn. J. Soil Sci. Plant Nutr.), 71, 826-833 [In Japanese with English summary].

20. Sugihara, S. et al. (1986) Kinetics of mineralization of organic nitrogen in soil. Nogyo kankyo gijutsu kenkyusho hokoku (Bull. Natl. Inst. Agro-Environ. Sci.), 1, 127-166 [In Japanese with English summary].

21. Sumida, H. et al. (2002) Fate of fertilizer nitrogen and compost nitrogen in long-term experiments on gray lowland soil in a cool region. Tohoku nogyo kenkyu center kenkyu houkoku (Bull. Natl. Agric. Res. Cent. Tohoku Reg.), 100, 49-59 [In Japanese with English summary].

22. Takahashi, S. \& Uenosono, S. (2001) Labeling of livestock manures with nitrogen-15 and nitrogen uptake by plant derived from these manures. Nogyo gijutsu (J. Agric. Sci.)
56, 412-415 [In Japanese].

23. Takahashi, S. et al. (2003) Short- and long-term effects of rice straw application on nitrogen uptake by crops and nitrogen mineralization under flooded and upland conditions. Plant Soil, 251, 291-301.

24. Tokunaga, T. et al. (2000) Variation of natural ${ }^{15} \mathrm{~N}$ abundance $\left(\delta^{15} \mathrm{~N}\right)$ in paddy rice supplied with chemical fertilizers and livestock manures, and estimation of soil-, manure- and fertilizer-derived $\mathrm{N}$ by the isotope mass balance method. Nippon dojo-hiryogaku zasshi (Jpn. J. Soil Sci. Plant Nutr.), 71, 447453 [In Japanese with English summary].

25. Ueda, T. \& Matsuguchi, T. (1994) Cycle of nitrogen. In Dojou seikagaku (Soil Biochemistry), Asakurashoten, Tokyo, 111-131 [In Japanese].

26. Ueno, H. \& Yamamuro, S. (2001) Fate of nitrogen derived from ${ }^{15} \mathrm{~N}$-labeled plant residues and composts in rice-planted paddy soil. Soil Sci. Plant Nutr., 47, 747-754.

27. Uenosono, S. \& Nagatomo, M. (1998) Effect of application of only manure on yield and quality of paddy rice. Kyushu nogyo kenkyu (Kyushu Agric. Res.), 60, 56 [In Japanese].

28. Uenosono, S. et al. (2004) Evaluation of nitrogen availability of composted poultry and sawdust cattle manures labeled with ${ }^{15} \mathrm{~N}$ on paddy field rice. Nippon dojo-hiryogaku zasshi (Jpn. J. Soil Sci. Plant Nutr.), 75, 313-319 [In Japanese with English summary].

29. Yamamuro, S. (1995) ${ }^{15} \mathrm{~N}$ tracer technique and environmentfriendly agriculture. ${ }^{15} \mathrm{~N}$ Information, 11, 1-4 [In Japanese].

30. Yamamuro, S. et al. (2002) Uptake of carbon and nitrogen through roots of rice and corn plants, grown in soils treated with ${ }^{13} \mathrm{C}$ and ${ }^{15} \mathrm{~N}$ dual-labeled cattle manure compost. Soil Sci. Plant Nutr., 48, 787-795. 